\section{Carefulness is important when analyzing epidemiological data}

To the Editor,

We have read the article by Keskinler et al. (1) with great interest. We would like to comment that analysis, results, and the conclusion of the study does not fulfill the authors' original hypotheses. The limitation of this study, originally stated by the author as "The number of events was not enough to establish underlying risk factors for six patients whose ECG changes were accompanied by significant changes in troponin values," is in direct contradiction with the stated hypothesis of the author. A scientific study must test its originally stated hypotheses; otherwise, it will misdirect its readers into thinking that the originally stated hypotheses are true. In Table 5, we can see that nearly all the patients have elevated troponin levels at the time of admission (0.1(0.1-0.2) IQR) cut-off value troponin 0.034 . The author states the concept of troponin elevation, meaning a rise in troponin levels from the levels at the time of admission.

More than half of the patients included in the study had a hip fracture (56/101). The author claims that the surgical procedure is the cause of elevated troponin levels; however, previously published studies show that the hip fracture itself is the cause of increased troponin levels $(2,3)$. In Table 7 , troponin values, which are analyzed as an outcome variable, should have been analyzed as a continuous variable; the baseline troponin level should also be included in the regression model. The third universal myocardial infarction (MI) definition includes the following changes in ECG as a sign of MI: PR segment, ORS complex, ST segment, and the T-wave abnormalities (4). However, the authors included some nearly normal signs of ECG, such as atrial premature contractions, as a sign of abnormal ECG.

As a result, subgroup analysis of neutral studies may increase the probability of misleading conclusions. We sincerely look forward to these issues being resolved.

\section{Fatih Yılmaz}

Department of Cardiology, University of Health Sciences, Koşuyolu Heart Training and Research Hospital; İstanbul-Turkey

\section{References}

1. Keskinler MV, Köstek O, Erok B, Telci Ö, Danacıoğlu YO, Oğuz A. Perioperative myocardial damage and the incidence of type 2 myocardial infarction in patients with intermediate and high cardiovascular risk. Anatol J Cardiol 2021; 25: 89-95. [Crossref]

2. Hietala P, Strandberg M, Kiviniemi T, Strandberg N, Airaksinen KE. Usefulness of troponin $\mathrm{T}$ to predict short-term and long-term mortality in patients after hip fracture. Am J Cardiol 2014; 114: 193-7. [Crossref]
3. Nordling P, Strandberg M, Strandberg NNG, Kiviniemi TO, Mäkelä KT, Airaksinen KEJ. Preoperative myocardial troponin T elevation is associated with the fracture type in patients with proximal femoral fracture. Scand J Surg 2019; 108: 305-12. [Crossref]

4. Thygesen K, Alpert JS, Jaffe AS, Simoons ML, Chaitman BR, White $\mathrm{HD}$, et al. Third universal definition of myocardial infarction. J Am Coll Cardiol 2012; 60: 1581-98. [Crossref]

Address for Correspondence: Dr. Fatih Yılmaz, Kartal Koşuyolu Yüksek İhtisas Eğitim ve Araştırma Hastanesi, Denizer Caddesi Cevizli Kavşağı No: 2 Cevizli, Kartal, İstanbul-Türkiye Phone: +90 2165001500

E-mail: fatihyilmaz_07@hotmail.com

(C) Copyright 2021 by Turkish Society of Cardiology -

Available online at www.anatoljcardiol.com

D0I:10.5152/AnatolJCardiol.2021.85601

\section{Author’s Reply}

To the Editor,

We are contented with the interest shown in our work. First of all, this is not an epidemiological study. We follow the definitions used in the guidelines. As it is clearly stated in the third universal definition of Ml, detection of rise and/or fall is essential in the diagnosis of $\mathrm{Ml}$, and assay-specific change is recommended in the European Society of Cardiology's non-ST-segment elevation MI guideline. Therefore, diagnosis solely based on the elevated baseline value is not appropriate in most of the patients. We have presented regression analysis results for ECG changes and troponin positivity separately. What we wanted to express as a limitation was that we could not assess the risk and predictors of combination of troponin positivity and ECG changes because of low number of events.

Troponin values might be assessed as a continuous outcome variable or might be used as a dichotomous variable if the same dichotomization is also used as a diagnostic criterion, as in MI. We are sure that the authors writing the letter to our manuscript are also using troponin-positive or troponin-negative definitions based on specific values or changes, as it is recommended by the guidelines. Therefore, we do not think it is an important issue for this study. We agree that the baseline troponin values might be included in the model as an independent predictor. We tested the model after including the baseline troponin values. Although some minor changes in the number occurred, the main results and the conclusion did not change.

The author(s) of the letter missed the main point in terms of ECG changes. As we have stated, our primary aim is to assess the risk of perioperative MI. Moreover, we wanted to present the perioperative ECG changes. We defined some criteria as major ECG changes; however, premature contractions were not among the major changes. We do not see any concern about presenting the frequency of any kind of arrythmias, including the benign ones. Moreover, we did not include premature contractions among the diagnostic criteria for acute MI. 
Miraç Vural Keskinler (D), Osman Köstek ${ }^{1}$ (D), Berrin Erok ${ }^{2}$ (D), Özge Telci3 ${ }^{3}$ (D), Onur Danacıoğlu4 (D), Aytekin Oğuz (D)

Department of Internal Medicine, Medeniyet University, Göztepe

Training and Research Hospital; İstanbul-Turkey

1Department of Oncology, Edirne Sultan 1. Murat State Hospital; Edirne-Turkey

2Department of Radiology, Cihanbeyli State Hospital; KonyaTurkey

3Department of Endocrinology, İstanbul Faculty of Medicine, İstanbul University; İstanbul-Turkey
4Department of Urology, Bakırköy Dr. Sadi Konuk Training and Research Hospital; İstanbul-Turkey

Address for Correspondence: Dr. Berrin Erok,

Prof. Dr. Cemil Taşcıoğlu Şehir Hastanesi, Radyoloji Kliniği, İstanbul-Türkiye Phone: +90 2129453000

E-mail: drberrinerok@hotmail.com

(C) Copyright 2021 by Turkish Society of Cardiology - Available online at www.anatoljcardiol.com 